DOi: $10.21554 /$ hrr.042005

\title{
ROLE OF ADDITIONAL ACTIVITIES AND COMPETITION IN THE TEACHING OF MATHEMATICS
}

Original scientific paper

\section{Maid Omerović a \\ SeadRešićc \\ Ahmed Palića \\ TarikBazdalića}

${ }^{a}$ Faculty of Education, University of Travnik, Bosnia and Herzegovina

${ }^{b}$ Department of mathematics, Faculty of Science, University of Tuzla, Bosnia and Herzegovina

Received: $2 / 11 / 2020$

Accepted: $3 / 23 / 2020$

\begin{abstract}
The development of science is essential when it comes to the development of society, while the mathematics necessary for the development of science. The fact that the children are all clearer, more capable and versatile, and their mathematical knowledge smaller and worse, motivated me to this research.How would our society be better you need to choose talented and creative young people who will represent the same company. One way of selecting children, and choosing the best are just competitions. In this work, attention will be focused on additional classes and competitions of teaching mathematics, as well as their importance in the education and development of children in schools. When it comes to gifted students, one of the main events where they can demonstrate their knowledge and skills are the competition.The overall objective of this research is to determine the extent to which the additional classes represented in schools and how many students go to additional classes and competitions in mathematics. The study included 103 primary school students in the municipality of Ilijaš. The results obtained in this study mostly on the representation of additional teaching of mathematics in schools or with, a small number of students. Because the necessary mathematical talent, the will and desire to learn mathematics. Viewed from the perspective that the disciples mathematics not so favorite subject, these are the expected results.
\end{abstract}

Keywords: extra classes, mathematics competition, student, teacher.

\footnotetext{
${ }^{1}$ Correspondence to:

Maid Omerović, Faculty of Education, University of Travnik, Bosnia and Herzegovin

E-mail: maid.omerovic@gmail.com
} 


\section{INTRODUCTION}

The gifted students and the teaching of them havealways been of particular interest to anyone who has had an education. Gifted students in mathematics teaching is a topic that every teacher or professor of mathematics should devote to. According to the rulebook on elementary education of gifted students, giftedness is a set of traits that enable a student to achieve aboveaverage results in one or more areas of human activity, and is conditioned by a high level of development of individual abilities, personal motivation and external encouragement. Accordingly, each mathematics teacher should specifically devote himself to such students and assist them in their continued growth and development, taking into account their personal interests, abilities, specific needs and potentials, going beyond the intended curriculum. Although gifted students have a higher level of intelligence than their peers, they can partially make up for most of their education deficiencies, often disadvantaged in the sense that they may or may not be able to reach their full potential, which can then lead to frustration, loss of self-esteem and serious difficulties in their continued progress. "The most that education can provide a child in his or her development is to help him and guide him to the area in which his talents are most appropriate, where he will be satisfied and professional." (by Daniel Jay Goleman) ${ }^{2}$

The additional teaching aims at enabling students who love mathematics and successfully acquire mathematical content in regular teaching to advance, deepen and expand those contents, and thus to stimulate even stronger motives for learning mathematics. (Vušović Lj., 76.)

Additional teaching of students motivates to creative work, independent work, develops the ability of logical thinking among students, develops creative and critical thinking, equips the student for selfeducation with the help of literature.

In general, additional teaching enables gifted students

${ }^{2} 20$ inspirirajucih citata o nastavnicima, https://skolski.ba/20inspirirajucih-citata-o-nastavnicima/54934/, 31.3.2020. to express and develop their mathematical skills. In addition to its extremely general educational function (providing students with the opportunity to acquire additional and deeper knowledge and skills), it also has a significant educational function (positively and strongly influences the intellectual, work, aesthetic and moral education of students - the positive qualities of students' personalities necessary for his actions in society). Every teacher-teacher in primary and secondary school needs to know the methodological criteria when recognizing students for additional teaching in mathematics.

That is why it is necessary that this ability for mathematics is noticed in the students at the right time and in the right way. The student should be recognized on the basis of his particular ability and aptitude for mathematics, especially his ability to think logically, then his reasoning at an elevated level of abstraction, then his quick generalization, and his ability to cope independently in problem situations; as well as the originality of solutions to problems and the posing of new problems (resilience and creativity of thinking), critical thinking and the like. Mathematics students' ability is correlated with various other intellectual abilities as well as personality traits, such as increased interest in mathematics, tendency towards clarity, precision, precision, criticality, perseverance, curiosity.

Mathematical abilities and aptitudes begin to be manifested partly in the older grades of primary school, and whether and to what extent they will be further developed depends on the conditions of life and learning, and especially on the impact through continuing mathematics, during further education. When it comes to gifted students we cannot overlook the topic of "competitions", since competitions, at least in our country, are a rare opportunity for students to test their knowledge and abilities, which go beyond the standard school curriculum. It is a challenge where they can measure their strengths with students outside the classroom in a material that goes beyond what is foreseen in the standard curriculum and gain a more realistic picture of their knowledge and abilities. In addition, some awards in upper elementary school grades may allow them to enroll in their preferred high school more easily because of the points they earn. 
The situation is different for teachers. There are no mechanisms in place to stimulate teachers to prepare students for the competition. There is also no legal obligation to do this, and teachers themselves, if we exclude the enthusiasm of few individuals, have no interest in competitions. There is an obligation to hold additional classes, but it is not known what their number should be when these classes are held (not scheduled), and the space in which they would be held in our overcrowded schools is a major problem. All these reasons provide a great excuse not to hold the preparation hours for the competition in the form of extra classes (except by a small number of enthusiasts). However, it is very important to emphasize that some schools are already changing this practice. This is another of the many indications of concern for gifted students that accompanies them during their schooling with us. In the past, the notion of giftedness has been associated solely with high intelligence ratios. (Vajagić Z., 3.)

It was based on the assumption that gifted students are born with a high level of intelligence and can be recognized by their high grades and final exam scores, and are able to excel in all fields, both in education and in life in general. The fact that students are different may be inappropriate but inevitable. Adaptation to diversity is a necessary price for productivity, high standards and an equal attitude towards all students "... the school will always be as good or bad as its teachers or their good ones. Goodwill alone is not enough. She needs a complement of professional competencies. "(Bach)

"We are not all equal, we do not all have the same minds, education works most effectively when these differences are taken into account, not when they are denied and ignored."
The responsibility of the school and teachers in the development of mathematically gifted students

The teacher plays a big role in discovering gifted students. Students gifted with mathematics need not be successful in other subjects, so it is not easy to identify them. It is important for the teacher to learn to recognize the needs of gifted students and their characteristics. Also, teachers who have a good relationship with their students are able to use that knowledge as a good guide to working with them, rather than separate the gifted students according to traditional tests. Teachers need special training and support in recognizing mathematical talent. Teachers working with gifted students should have a good knowledge of mathematical content, but if the school has only a few gifted students and does not have a suitable teacher, they should be allowed to work with a suitable mentor outside their home school. The harmonized program must be so arranged that the mathematical knowledge acquired in one school year is not repeated or interrupted in another. (Elezović N., 45.)

The school should have an organized support system that includes the provision of appropriate books, technology and staff for trained people. When fulltime and extensive experiences with gifted students are provided in full-time teaching, the potential for enriching the educational community is created. Namely, other students in these conditions develop increased interest and with a little help can master more demanding tasks. Therefore, all students have the opportunity to learn according to their abilities if they are offered a variety of assignments and teaching materials while teaching, following the rhythm of their learning and monitoring their needs. (Vejagić Z., 32.) 


\section{METHODS}

\section{Procedures}

The basic procedures in this research are:

- prior to the research, preparations were made in the form of research and analysis of various scientific papers on the subject of additional teaching / competition.

- In accordance with the topic of this transversal research, the survey was done using a 10-item item scale on the importance and role of additional teaching and competition in mathematics teaching, and Ilijaš students were interviewed;

- cooperation with the mathematics teachers of this elementary school was made, explaining the importance of conducting this research and agreeing to conduct it with the students during the class.

- after brief instruction, four grades of elementary school students, a total of 103 students were required to respond to ten thematic statements by selecting one of the response options offered

- the students voluntarily participated in the examination, were aware of the fact that the survey was anonymous, they were able to ask questions in case of ambiguity, as well as information that the data would be used solely for scientific purposes and that accuracy and answering of all questions asked were important for research, so we asked them to collaborate.

\section{Sample research}

The sample of this research consists of students of VI, VII, VIII and IX grades. The sample includes 103 students, 30 male and 73 female. A total of 25 th grade students, 27 th grade students, 28 8th grade students and 23 9th grade students out of which 9 students once participated in any of the competitions

\section{Research instrument}

The reliability of the survey instrument was verified by the well-known Cronbach Alpha coefficient, which for 14 points is 0.816 , which represents a good internal consistency and indicates that it is a reliable measuring instrument.

In order to examine students' attitudes towards additional teaching and mathematics competitions, a student survey questionnaire was used, which included 10 alternativetype questions. The questionnaire provided ratings (1 to 5) for their evaluation. We will analyze and compare students by considering grades 5 and 4 to be more or less in agreement with students, while 2 and 1 will be more or less in agreement. If a student has rated a claim with a grade of 3, we will consider that he or she is hesitant to make that claim.

In the questionnaires, students were asked to write a grade in mathematics, a school achievement at the end of the year, as far as going to additional classes. The questions in the instrument relate to students' attitudes toward additional teaching in the teaching process, what is the teacher's interest in maintaining an additional section, does the student burden additional teaching, do they neglect other subjects because of additional teaching, do competitions only include mathematically gifted students?

\section{Statistical analysis}

After the data collection method, the statistical program SPSS 19.0.1 was applied for the data processing method and interpretation of the obtained results. From statistical procedures we calculated frequencies, sum, arithmetic mean, standard deviation, standard error of arithmetic mean, as well as one-factor analysis of variance ANOVA, bivariate correlation analysis.

\section{RESEARCH RESULTS}

In accordance with the research objective, the relevant parameters of descriptive and inferential statistics were analyzed and presented. 


\begin{tabular}{|c|c|c|c|c|c|c|}
\hline Claims & $\mathbf{N}$ & Minimum & Maximum & Sum & Mean & Std. Deviation \\
\hline $\begin{array}{l}\text { 1. How many students once participated } \\
\text { in the competition? }\end{array}$ & 103 & 1.00 & 2.00 & 197.00 & 1.9126 & 1.28377 \\
\hline 2. Math is an interesting subject for me. & 103 & 1.00 & 5.00 & 327.00 & 3.1748 & 1.13265 \\
\hline $\begin{array}{l}\text { 3. The teacher teaches me mathematics in } \\
\text { an interesting way. }\end{array}$ & 103 & 1.00 & 5.00 & 324.00 & 3.1456 & 1.10620 \\
\hline $\begin{array}{l}\text { 4. Knowledge of mathematics will be } \\
\text { important to me in further education. }\end{array}$ & 103 & 1.00 & 5.00 & 326.00 & 3.1650 & 1.07646 \\
\hline $\begin{array}{l}\text { 5. I am satisfied with my knowledge in } \\
\text { mathematics in relation to my abilities, } \\
\text { knowledge. }\end{array}$ & 103 & 1.00 & 5.00 & 288.00 & 2.7961 & 1.03241 \\
\hline $\begin{array}{l}\text { 6. I would love to go for additional } \\
\text { classes as this expands my knowledg. }\end{array}$ & 103 & 1.00 & 5.00 & 248.00 & 2.4078 & 1.07043 \\
\hline $\begin{array}{l}\text { 7. Only mathematically gifted students go } \\
\text { to competition. }\end{array}$ & 103 & 1.00 & 5.00 & 281.00 & 2.7282 & .75659 \\
\hline $\begin{array}{l}\text { 8. Teachers are interested in organizing } \\
\text { additional classes. }\end{array}$ & 103 & 1.00 & 5.00 & 301.00 & 2.9223 & .87098 \\
\hline $\begin{array}{l}\text { 9. Additional classes burdening students } \\
\text { and takes Leisure. }\end{array}$ & 103 & 1.00 & 5.00 & 333.00 & 3.2330 & .79464 \\
\hline $\begin{array}{l}\text { 10. Due to the overload from extra } \\
\text { classes, I neglect other subjects. }\end{array}$ & 103 & 1.00 & 5.00 & 340.00 & 3.3010 & .91646 \\
\hline $\begin{array}{l}\text { 11. The teacher is willing to help in } \\
\text { learning? }\end{array}$ & 103 & 1.00 & 5.00 & 309.00 & 3.0000 & .95998 \\
\hline Valid N (listwise) & 103 & & & & & \\
\hline
\end{tabular}

The role and importance of additional teaching and competition in mathematics teaching is presented in this paper using 10 points (additional 3 questions are: about the grade at mathematics at the end of the year, about success in school and whether students participated in the competition) with the aim of find out the views of elementary school students on the topic.

The results show that the mean values range from $\mathrm{M} \pm \mathrm{SD}=1.9126 \pm .28377$ for claiming how many students once participated in the competition, to $\mathrm{M} \pm$ $\mathrm{SD}=3.3010 \pm .91646$ for claiming that students due to the overload of the course material, they neglect other subjects.

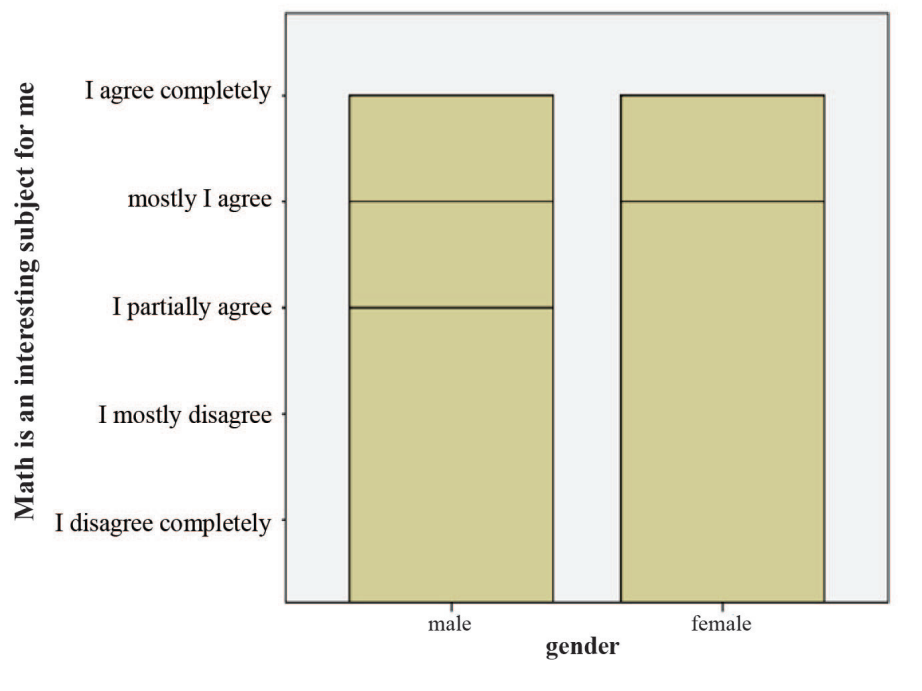

Histogram 1. Answers to the question "Math is an interesting subject for me" 
Responses to the statement "Mathematics is an The indicators for the mentioned variable are interesting subject for me" are shown in histogram 1. arithmetic mean $\mathrm{M}=3.17$ with standard error 0.098 and the basic indicators of descriptive statistics are and standard deviation SD $=0.998$, the calculated shown in table 1. (as for other variables). coefficient of variability is $31.63 \%$ and with $95 \%$ certainty the interval in which the arithmetic mean of the population is between 3.073 and 3.267 .

Table 2. Year-end mathematics grade

\begin{tabular}{llcccc}
\hline & Frequency & Percent & Valid Percent & Cumulative Percent \\
\hline \multirow{4}{*}{ Valid } & 4 & 3.9 & 3.9 & 3.9 \\
& sufficient & 12 & 11.7 & 11.7 & 15.5 \\
& good & 46 & 44.7 & 44.7 & 60.2 \\
& very good & 27 & 26.2 & 26.2 & 86.4 \\
& excellent & 14 & 13.6 & 13.6 & 100.0 \\
& Total & 103 & 100.0 & 100.0 & \\
\hline
\end{tabular}

Table 2 provides important and interesting information. The first column contains the categories of the success variables (failure, sufficient, good, very good and excellent. The second column of the Frequency table lists the categories for which the frequencies have been determined and, in addition, the total sample size.

The Percent column speaks of the percent correct representation of grades in students relative to the total number of respondents 103 in our case. And the Valid Percent column speaks of the percentage of students' grades at the end of the year, but this time against the valid number of respondents 103 in the said case.

The Cumulative Percent column gives the cumulative percentages, that is, the sum of the percentages of a given grade with the percentages of the previous grades.

Looking at the following table, we can see that only 14 students out of 103 examinees have an excellent (5) grade in mathematics. The average grade in mathematics is 3 or $44.7 \%$. This is shown in the following histogram 2 .

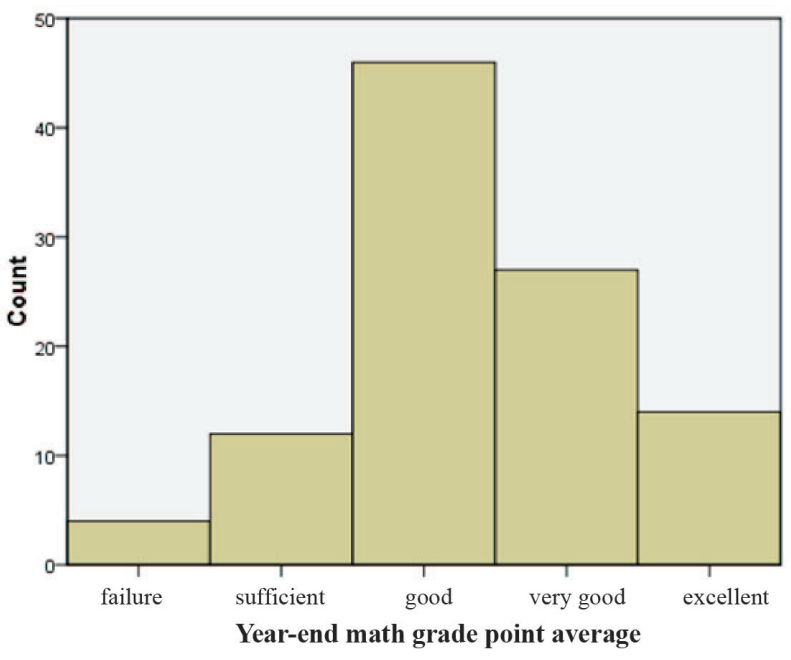

Histogram 2. Year-end math grade point average

Table 3. Teachers are interested in organizing additional classes

Teachers are interested in organizing additional classes

\begin{tabular}{ccc} 
& Valid & 103 \\
$\mathrm{~N}$ & Missing & 0 \\
\hline Mean & 2.9223 \\
Median & 3.0000 \\
Mode & 3.00 \\
\hline
\end{tabular}


The results obtained for the arithmetic mean of Mean correspond to 2.69 children, and for the median and mode 3 indicate below-average interest of teachers in holding additional classes.

\begin{tabular}{llcccc}
\hline & Frequency & Percent & Valid Percent & Cumulative Percent \\
\hline \multirow{2}{*}{ I disagree completely } & 3 & 2.9 & 2.9 & 2.9 \\
Valid & 31 & 30.1 & 30.1 & 33.0 \\
& I partially agree & 43 & 41.7 & 41.7 & 74.8 \\
& mostly I agree & 23 & 22.3 & 22.3 & 97.1 \\
& I agree completely & 3 & 2.9 & 2.9 & 100.0 \\
Total & 103 & 100.0 & 100.0 & \\
\hline
\end{tabular}

Looking at the spreadsheet on whether students think teachers are interested in taking additional classes, we see that $30.1 \%$ of them said "mostly disagree" and $41.7 \%$ said "partially agree". This leads us to suspect that teachers are not interested in holding additional classes, either because of the fact that it takes them extra time or because they are not paid or because of inadequate school conditions.

Table 4. Do additional classes take away the student's free time?

\begin{tabular}{|c|c|c|c|c|c|}
\hline & & Frequency & Percent & Valid Percent & Cumulative Percent \\
\hline \multirow{6}{*}{ Valid } & I disagree completely & 1 & 1.0 & 1.0 & 1.0 \\
\hline & mostly disagree & 14 & 13.6 & 13.6 & 14.6 \\
\hline & I partially agree & 54 & 52.4 & 52.4 & 67.0 \\
\hline & mostly I agree & 28 & 27.2 & 27.2 & 94.2 \\
\hline & I agree completely & 6 & 5.8 & 5.8 & 100.0 \\
\hline & Total & 103 & 100.0 & 100.0 & \\
\hline
\end{tabular}

We can see from the table that only $5.8 \%$ of students fully believe that extra classes are taking up their spare time, and $52.4 \%$ partially agree. From this we can see that students are not interested in additional teaching because it overloads them, deprives them of their spare time and therefore neglects other subjects. This may be the reason why few students go for additional classes. Although teachers also have a role to play in this, they must encourage students to become more knowledgeable, as this helps them further their education..

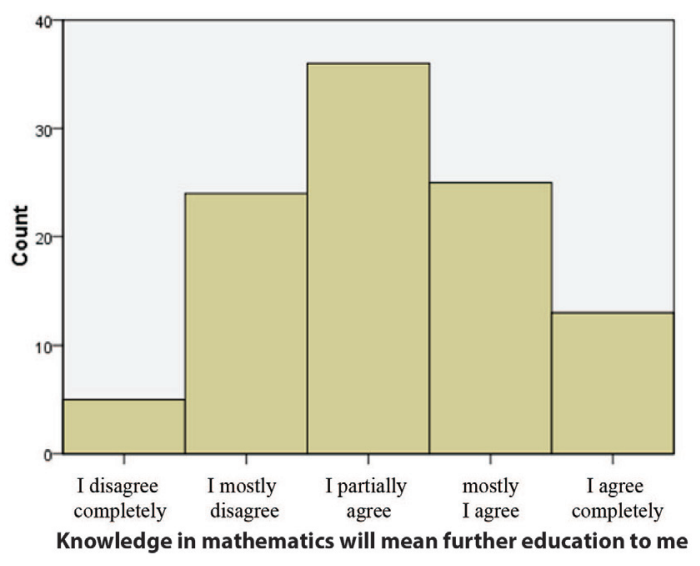

Histogram 3. Is knowledge of mathematics important in further education of students? 
Students are aware of the importance of mathematics, and desire for mathematics as a subject for the students, its content, in further education. And that this is a to explain the material in a simple way, to organize subject that needs to devote time, learn and practice the additional classes and to develop a competitive spirit material. But it is up to the teachers to develop a desire and will to prepare for and go to competitions.

Table 5. One-way analysis of ANOVA variance for the independent end-of-year assessment variable in mathematics

\begin{tabular}{cccccc}
\hline & Sum of squares & df & $\begin{array}{c}\text { Arithmetic } \\
\text { mean of the } \\
\text { square }\end{array}$ & F & Sig. \\
\hline Analysis of different groups & 25.361 & 4 & 6.340 & 11.945 & .000 \\
Analysis of the same subjects & 52.018 & 98 & .531 \\
Total & 77.379 & 102 & \\
\hline
\end{tabular}

The statistical significance of these deviations is determined by the value of Sig.

Given that the value of $\mathrm{F}=11,945$ and Sig. $=.000$ less than .05 , it can be stated in the report that there is a statistically significant difference between the students (considering their grades at the end of the year in mathematics) in terms of whether teachers are willing to organize additional classes.

Table 6. Two-factor univariate analysis of variance - statistical significance, for the dependent variable "I am satisfied with my degree in mathematics, given my abilities “

\begin{tabular}{lcccc}
\hline Source & df & $\begin{array}{c}\text { The arithmetic mean of } \\
\text { the square }\end{array}$ & F & Sig. \\
\hline Corrected Model & 15 & 3.973 & 7.036 & .000 \\
Intercept & 1 & 313.575 & 555.331 & .000 \\
evaluation & 4 & 2.832 & 5.015 & .001 \\
NMPNZN & 4 & .953 & 1.688 & .160 \\
evaluation * NMPNZN & 7 & .558 & .989 & .445 \\
Error & 87 & .565 & & \\
Total & 103 & & & \\
Corrected Total & 102 & & & \\
\hline
\end{tabular}

This table gives us information about statistical significance. The lines in which the grade is written, The teacher teaches me in an interesting way the math and Grade * NMPNZN, as well as columns F and Sig. They are the data necessary to interpret the results. Within the order of ratings it is seen that the measure $\mathrm{F}=5.015$ and that it is statistically significant at the level of .05 because Sig. $=.001$, and in the NMPNZN that $F=1.688$ with statistical insignificance because
Sig. $=.160$. These are the main effects of the grade and NMPNZN on the level of "I am satisfied with my math knowledge" and we see that the grades have statistical significance and the NMPNZN has no significance. In the grade of $*$ NMPNZN we have the value of statistics $\mathrm{F}=.989$ and its significance Sig. $=.445$, which means that there is no interaction between the grade and NMPNZN regarding the influence on satisfaction with the knowledge in mathematics. 


\begin{tabular}{llcc}
\hline & Correlation & VDNZP & gender \\
\hline \multirow{4}{*}{ VDNZP } & Pearson Correlation & 1 & .082 \\
& Sig. (2-tailed) & & .409 \\
& $\mathrm{~N}$ & 103 & 103 \\
gender & Pearson Correlation & .082 & 1 \\
& Sig. (2-tailed) & .409 & \\
& $\mathrm{~N}$ & 103 & 103 \\
\hline
\end{tabular}

Our example shows that there is a very small correlation between the desire for additional teaching and the gender of students, since $r=.082$ is very small, suggesting a very weak association.

Significance of Sig. $=.409$ (no statistically significant correlation) indicates the degree of confidence of the results if the study is repeated.

\section{DISCUSSION}

The results of this study, involving students in grades VI, VII, VII and IX, totaling 103 students, show that the students confirmed the following statements:

- Very few students go to additional classes, that is, they once participated in the competition. For the most part, they are excellent students, with a final grade of 5 at the end of the year. Viewed, that's about 2-3 students per class.

- Students partially (male) and generally agree (female) that mathematics is an interesting subject for them.

- Most students have a grade of 3 as the closing at the end of the year. From this we see that mathematics is still a difficult subject for students.

- Opinions were divided as to whether the teacher was willing to assist students in mastering the material. Mostly those with a passing grade of 4 and 5 responded positively, which was expected.

- Students are satisfied with their math grades, which means that they have no ambition for higher learning intensity and no additional teaching.
- Only mathematically gifted students want to go to extra classes as this expands their knowledge.

- Most students find that extra classes are timeconsuming and burdensome, while those who go to additional classes do not think so.

- The survey revealed that teachers are not willing to take additional classes. In some schools, the conditions are not even adequate.

- Only students who love math would like to go to extra classes. Therefore, we see that there is little interest in students for additional teaching.

- In terms of research, only mathematically gifted students go to competitions because they want them, with them teachers can achieve better results, and also because of their knowledge and ability, they do not need extra classes but only instruction and guidance, and do the rest at home.

What is important to note is that different answers were given by "better" students, that is, those who love maths, who have 4 or 5 as a final grade and those who go to additional classes and who once participated in the competition, which was taken in the course of conducting the research. Also, the question of whether teachers have the will to organize additional classes is questionable, because it does not depend largely on them, but on the school itself and the students in the class. Where there is poor passing grade, there is also little interest in additional teaching.

There are many factors that influence the organization of additional classes and competitions that need to be considered in the course of the research. 
There is not a lot of research work on this topic. One of them we have come to is the work of TijanaVlahovic from the Faculty of Science in Novi Sad, which explored the role of additional teaching and competition from the perspective of competitors and non-competitors. We can say that the data obtained is similar to ours, although its work was conducted on a larger sample of respondents in schools in Serbia. Therefore, the contestants recognize the great importance of additional teaching and competitions in their schooling, support additional classes, like to go to competitions and do not neglect other subjects and school obligations because of it. While noncontestants see opposite answers from competitors.

\section{CONCLUSION}

The role and importance of mathematical competitions in elementary school are too large to be absolutely evocative of a single work. Mathematics sections at school are very useful activities for developing and maintaining an interest in learning mathematics. The analysis and the survey showed that children who love mathematics and have a good final grade, mathematical competitions as well as additional classes in general have multiple meanings. They are aware of its importance in their further education because of this they want to expand their knowledge and go to additional classes. In general, "excellent" students are more committed to school and take it more seriously, and with such children it is easier to work and achieve better results. It is imperative that children understand the importance of mathematics and how widespread it is in mathematics, not only in the natural sciences but also in the social sciences. It is true that mathematics can be developed for its own sake, while only later can we get its application, however, it cannot be disputed that it is necessary as a tool in any science or research. Competition is just one way that can get kids more interested in learning about math and developing their abilities.

Especially gifted children are motivated to compete, because for them, it is a challenge to weigh their knowledge with students outside their class and in material that goes beyond the standard school curriculum. The situation is different for teachers. There are no mechanisms in place to stimulate teachers to prepare students for the competition. There is also no legal obligation to do this, and teachers themselves, if we exclude the enthusiasm of few individuals, have no interest in competitions. And finally, I would dare to encourage math teachers to devote themselves to mathematically gifted children, to support them, to motivate them, to work with them, because, in addition to helping those children, they thus upgrade themselves and their knowledge. It is no shame that we sometimes learn something from the students as well.

Finally, the importance of mathematics competitions is multifaceted, both because of the children themselves, and because of the quality of our society in the future.

\section{REFERNCES}

Elezović, N. (2007). Matematička natjecanja i rad s darovitim učenicima [Math competitions and working with gifted students]. Element, Zagreb

Vušović, Lj. (1987). Razvijanje interesa i stvaralačkog rada u nastavi matematike [Developing interest and creative work in mathematics teaching]. Element, Zagreb

Vajagić, Z. (2014). Rad s matematički nadarenim učenicima $u$ osnovnim školama [Working with mathematically gifted students in primary schools]. Odjel za matematiku Sveučilišta Josipa Jurja Strossmayera, Osijek.

Portal školski.ba, 20 inspirirajućih citata o nastavnicima [20 inspirirajućih citata o nastavnicima].https://skolski.ba/20inspirirajucih-citata-o-nastavnicima/54934/, 31.3.2020. 